\title{
INFLUENCE OF IRRIGATION LEVELS, ANTITRANSPIRANTS AND POTASSIUM SILICATE ON GROWTH, FRUIT YIELD AND QUALITY OF SWEET PEPPER PLANTS (Capsicum annuum L.) GROWN UNDER DRIP IRRIGATION Kamal, A. M. \\ Veget. Res. Dept., Hort. Res. Inst., Agric. Res. Center, Giza, Egypt
}

\begin{abstract}
Two field experiments were conducted at a private farm near EL-Mansoura city, El-Dakahlia Governorate, Egypt, during the two successive seasons of 2011 and 2012 to study the effect of three water irrigation levels, the first was $2600 \mathrm{~m}^{3} \mathrm{fed}^{-1}$ as the control treatment (the traditional irrigation amount used by the farmers in the area), the $2^{\text {nd }}$ and the $3^{\text {rd }}$ treatments were 1800 and $1000 \mathrm{~m}^{3}$ fed $^{-1}$, respectively, as deficit irrigation treatments as well as four foliar applications, i.e., control, magnesium carbonate, kaolin and potassium silicate on growth, chemical composition, yield, water use efficiency and fruit quality of sweet pepper plants (Gedeon F1 Hybrid) cultivated under drip irrigation system in clay-loam soil at northern of Nile Delta lands. The main results could be summarized as follows:

- Applying the high irrigation water level $\left(2600 \mathrm{~m}^{3} \mathrm{fed}^{-1}\right)$ or the deficit level $\left(1800 \mathrm{~m}^{3}\right.$ $\mathrm{fed}^{-1}$ ) combined with foliar application of kaolin or potassium silicate showed the highest significant values of all studied vegetative growth aspects, i.e., stem diameter, relative growth rate, net assimilation rate and leaf relative water content.

- Applying $2600 \mathrm{~m}^{3}$ fed $^{-1}$ combined with foliar application of potassium silicate and 2600 or $1800 \mathrm{~m}^{3} \mathrm{fed}^{-1}$ combined with foliar application of kaolin or potassium silicate significantly increased NPK uptake by sweet pepper plants foliage.

- Applying $1000 \mathrm{~m}^{3} \mathrm{fed}^{-1}$ combined with foliar application of kaolin or potassium silicate significantly increased total chlorophyll contents in sweet pepper leaves.

- All studied yield characteristics, i.e., number of fruits per plant, average fruit weight, early yield and total yield per feddan as well as water use efficiency were significantly increased by applying $1800 \mathrm{~m}^{3} \mathrm{fed}^{-1}$ of irrigation water combined with foliar application of kaolin or potassium silicate.

- The highest significant values of vitamin C, total soluble solids, reducing sugars and total sugars contents in sweet pepper fruits were significantly affected by applying the deficit irrigation treatments (1800 or $1000 \mathrm{~m}^{3} \mathrm{fed}^{-1}$ ) combined with foliar application of kaolin or potassium silicate.

- Fruit flesh thickness was significantly increased by applying $2600 \mathrm{~m}^{3} \mathrm{fed}^{-1}$ combined with kaolin or potassium silicate foliar application.

- The highest net return was obtained by applying $1800 \mathrm{~m}^{3} \mathrm{fed}^{-1}$ combined with foliar application of kaolin; such treatment returns the highest benefit-cost ratio (2.51).

In conclusion, this investigation demonstrate that irrigation sweet pepper plants with $1800 \mathrm{~m}^{3}$ fed $^{-1}$ combined with kaolin foliar application (4\%, 4 times during the season) could be recommended to improve the vegetative growth characteristics, chemical composition, total yield, water use efficiency and fruit quality, saving about $30 \%$ of the total used irrigation water quantity in sweet pepper production. Such treatment can be recommended under drip irrigation system in clay-loam soil at northern of Nil Delta lands, giving the highest net return and benefit-cost ratio to the farmers.
\end{abstract}




\section{INTRODUCTION}

Sweet pepper (Capsicum annuum L.) is one of the most important, popular and favorite vegetable crops cultivated in Egypt for local consumption and exportation. To achieve both water and food security, Egypt has to adapt alternative strategies directed towards efficient management of Nile River irrigation water particularly in Nile Delta lands.

Since sweet pepper plants are very sensitive to water stress, management of irrigation water is very important to produce economic yield and good fruit quality. Under water stress conditions, root density of pepper plants was reduced by about $20 \%$ compared with sufficiently irrigated plants (Silber, 2005), this in turn reflected on yield aspects (Ismail, 2010). Therefore, increasing productivity and irrigation efficiency under water stress conditions are greatly required. Deficit irrigation was proposed long time ago as a technique that irrigates the entire root zone with less evapotranspiration and leads to reduce the irrigation water use with maintaining farmers' net profits (Hoffman et al., 1990). Thus, deficit irrigation can be used as a practical technique to save large amounts of irrigation water.

Another technique that claim to reduce water use by plant is the reflectance type of antitranspirants as magnesium carbonate and kaolin, which are natural white materials form a coating film on the leaves, it increase the leaf reflectance by reflecting the radiation and increase the vapour pressure gradient and thus reduce transpiration (Glenn et al., 2002 and Creamer et al., 2005). In this respect, Abd El-Aal et al. (2008) mentioned that foliar application of $\mathrm{MgCO}_{3}$ at rate $2 \%$ gained more growth vigor and more fruits yield as well as better physical and chemical properties of eggplant compared with no-treated plants. Kaolin also is an important material used in this concern, it is considered as an effective natural antitranspirant and was reported to mitigate the negative effects of water deficiency and environmental stresses, such as heat stress and sunburn damage as well as suppress diseases and protect crops from insect pests (Kahn and Damicone, 2008). Spraying tomato plants with $5 \%$ of kaolin suspension improved water status and yield under water stress conditions (Srinivasa Rao, 1985). Creamer et al. (2005) illustrated that applications of kaolin at hot temperatures might help hot Chile pepper plants from being subjected to severe water stress.

Many researchers mentioned the role of silicon in plant resistance to both biotic and abiotic stress including drought (Adatia and Besford, 1986; Efimova and Dokynchan, 1986; Hanafy et al., 2008 and Crusciol et al., 2009). Potassium silicate is a source of highly soluble silicon; it is used in agricultural production system primarily as a silicon fertilizer (Romero-Aranda and Cuartero, 2006 and Abou-Baker et al., 2011). Many studies demonstrated that silicon has been shown to have several distinct advantages in improving plant growth, chemical composition and productivity as well as fruit quality of several plants (Romero-Aranda and Cuartero, 2006 on tomato; Lynch, 2008 on grapes and banana; Crusciol et al., 2009 on potato and Abou-Baker et al., 2011 on faba bean). 
The objective of the present investigation was to study the effect of irrigation levels, some antitranspirants and potassium silicate as well as their interactions on growth, fruit yield and quality of sweet pepper plants cultivated under drip irrigation system at northern of Nile Delta lands.

\section{MATERIALS AND METHODS}

Two field experiments were conducted at a private farm near ELMansoura city, El-Dakahlia Governorate, Egypt, during the two successive seasons of 2011 and 2012 to study the effect of irrigation levels, some antitranspirants and potassium silicate on growth, chemical composition, yield, water use efficiency and fruit quality of sweet pepper plants cultivated under drip irrigation system in clay-loam soil at northern of Nil Delta lands. Table 1 shows some physical and chemical properties of the experimental soil before planting, according to the methods described by Page (1982).

Table 1: Physical and chemical properties of the experimental soil

\begin{tabular}{|l|c|c|l|c|c|}
\hline \multirow{2}{*}{ Physical properties } & \multicolumn{2}{|c|}{ Value } & \multirow{2}{*}{ Chemical properties } & \multicolumn{2}{|c|}{ Value } \\
\cline { 2 - 3 } & $\begin{array}{c}\mathbf{1}^{\text {st }} \\
\text { season }\end{array}$ & $\begin{array}{c}\mathbf{2}^{\text {nd }} \\
\text { season }\end{array}$ & & $\begin{array}{c}2^{\text {nd }} \\
\text { season }\end{array}$ & Season \\
\hline Sand (\%) & 24.2 & 21.4 & Available N (\%) & 0.16 & 0.19 \\
\hline Silt (\%) & 32.6 & 33.5 & Available P $(\mathrm{ppm})$ & 8.9 & 12.8 \\
\hline Clay (\%) & 43.2 & 45.1 & Available K $(\mathrm{ppm})$ & 255 & 289 \\
\hline Texture class & Clay-loam & Clay-loam & Bulk Density (gm/cm $\left.{ }^{3}\right)$ & 1.42 & 1.38 \\
\hline Organic matter (\%) & 1.7 & 1.3 & Field capacity (\%) & 35.1 & 34.6 \\
\hline $\mathrm{CaCO}_{3}$ & 2.8 & 3.0 & Wilting point (\%) & 15.3 & 16.4 \\
\hline $\mathrm{pH}$ & 8.2 & 8.0 & Available water (\%) & 14.1 & 15.7 \\
\hline $\mathrm{EC} \mathrm{dSm}{ }^{-1}$ & 0.79 & 0.84 & Saturation (\%) & 84.9 & 84.4 \\
\hline
\end{tabular}

On March, $1^{\text {st }}$ week of both seasons, 45 day old sweet pepper seedlings, Gedeon F1 Hybrid, were transplanted in open field at $40 \mathrm{~cm}$ apart on one side of the ridge. The experiment was adopted in a split plot design with three replicates, containing 12 treatments, which were the combination between three water irrigation levels, the first was $2600 \mathrm{~m}^{3} \mathrm{fed}^{-1}$ as a control treatment (the traditional irrigation water amount by farmers in the area), the $2^{\text {nd }}$ and the $3^{\text {rd }}$ treatments were 1800 and $1000 \mathrm{~m}^{3} \mathrm{fed}^{-1}$ as deficit irrigation treatments as well as four foliar applications, i.e., control (tap water), magnesium carbonate, kaolin and potassium silicate. Water irrigation levels were distributed in the main plots, whereas the foliar spraying treatments were arranged in the sub plots. The experimental unit consisted of four ridges each of $1 \mathrm{~m}$ wide and $5 \mathrm{~m}$ long with an area $20 \mathrm{~m}^{2}$. A distance of $2 \mathrm{~m}$ was left between each irrigation treatments to avoid the infiltration of water irrigation. Drip irrigation was used from the beginning to the end of the two seasons using Nile water with EC of $0.74 \mathrm{dSm}^{-1}$. The drippers used were of a standard $4 \mathrm{~L} \mathrm{~h}^{-1}$ discharge at 1.5 bar working pressure. The irrigation treatments started after 35 days from sweet pepper transplanting. The amount of irrigation water at different treatments were adjusted using a water counter and were added according to growth stage of sweet pepper plants during growth season. 
Magnesium carbonate $\left(\mathrm{MgCO}_{3}\right)$ and kaolin (Aluminum silicate) powder, agriculture grade, were used as a fine mist foliar application at $4 \%$ till run-off with care being taken to cover all plant foliage. Potassium silicate $\left(\mathrm{K}_{2} \mathrm{SiO}_{3}\right)$ in a powder form (manufactured by Fusion chemicals Co., Ltd., India), contain $22.5 \% \mathrm{SiO}_{2}$ and $10.25 \% \mathrm{~K}_{2} \mathrm{O}$, was dissolved first in hot water and used as foliar spray at $1.5 \mathrm{~kg} \mathrm{fed}^{-1}$ in every addition. Foliar application of magnesium carbonate, kaolin and potassium silicate were applied 4 times starting 35 days after transplanting and repeated at 30 days intervals during the growth seasons using spreading agent (Super Film $1 \mathrm{ml} / \mathrm{l}$ ). The untreated plants (control) were sprayed with tap water using the same spreading agent only. The other agricultural practices for growing sweet pepper plants were followed according to the instruction laid down by the Egyptian Ministry of Agriculture, Egypt.

Five plants from each plot were randomly taken for determination of stem diameter (105 days after transplanting), foliage dry weight and leaf area per plant ( 75 and 105 days after transplanting). Foliage dry weight and leaf area were used to calculate relative growth rate (Hunt, 1990) and net assimilation rate (Gardner et al., 1985) as follows:

$\operatorname{RGR}\left(\mathrm{mg} / \mathrm{gm}\right.$ day $\left.^{-1}\right)=\left(\left(\ln \mathrm{W}_{2}-\ln \mathrm{W}_{1}\right) /\left(\mathrm{T}_{2}-\mathrm{T}_{1}\right)\right) \times 1000$

$\operatorname{NAR}\left(\mathrm{mg} / \mathrm{cm}^{2}\right.$ day $\left.^{-1}\right)=\left(\left(\mathrm{W}_{2}-\mathrm{W}_{1}\right) /\left(\mathrm{T}_{2}-\mathrm{T}_{1}\right)\right) \times\left(\left(\ln \mathrm{LA} \mathrm{A}_{2}-\ln \mathrm{LA} \mathrm{A}_{1}\right) /\left(\mathrm{LA}_{2}-\mathrm{LA} \mathrm{A}_{1}\right)\right)$ $X 1000$

Where; RGR: Relative growth rate; NAR: Net assimilation rate; In: Natural logarithm; $W_{1}$ and $W_{2}$ : Dry weight of plant shoots at time one and time two (in gram), respectively; $T_{1}$ and $T_{2}$ : Time one and time two, respectively (in day); $\mathrm{LA}_{1}$ and $\mathrm{LA}_{2}$ : Leaf area/ plant (Koller, 1972) at time one and time two, respectively $\left(\mathrm{cm}^{2}\right)$.

Leaf relative water content (LRWC) was determined in the fully expanded topmost leaf of the main shoot according to the methods of Turner (1981) by recording the fresh weight of the leaves sample and then the leaves were immersed in distilled water. After 2 hours, the leaves were removed, the surface water was blotted-off and the turgid weight recorded. Samples were then dried in an oven at $70^{\circ} \mathrm{C}$ to constant weight. Leaf relative water content was calculated using the following formula:

LRWC $(\%)=((F W-D W) /(T W-D W)) \times 100$

Where; FW: Fresh weight; DW: Dry weight; TW: Turgid weight.

At 105 day after transplanting, representative samples of 5 plants from each plot were used to determine N, P and K contents (\%) in foliage dry weight. Total nitrogen was determined according to the methods described by Bremner and Mulvaney (1982); phosphorus was estimated colormetrically according to Olsen and Sommers (1982) and potassium was determined flame photometrically as described by Jackson (1973). N, P and K uptake were calculated based on mineral content (\%) and foliage dry weight. Representative samples from the $4^{\text {th }}$ upper leaves were taken to determinate total chlorophyll content (SPAD units) using a portable leaf chlorophyll meter (Minolta Model SPAD 501) according to Murquard and Timpton (1987).

All harvested fruits from each plot at marketable green ripe stage along the season were used to determine number of fruits per plant, average fruit weight and total yield (ton fed ${ }^{-1}$ ). Early yield (ton fed ${ }^{-1}$ ) was calculated 
from the first three pickings. Water use efficiency (WUE) was calculated according to the equation of Begg and Turner (1976) as follows:

WUE $\left(\mathrm{kg} / \mathrm{m}^{3}\right)=$ yield $\left(\mathrm{kg} \mathrm{fed}^{-1}\right) /$ water quantity $\left(\mathrm{m}^{3} \mathrm{fed}^{-1}\right)$.

A representative sample of 10 sweet pepper fruits from each experimental plot at the marketable green ripe stage was taken from the $3^{\text {rd }}$ harvest for determination of fruits quality characteristics, i.e., fruit flesh thickness, vitamin C, total soluble solids (TSS) according to the methods described by AOAC (1990). Reducing sugars and total sugars in fruits were analyzed according to the method of Sadasivam and Manickam (1992) and Sen et al. (2005), respectively.

The obtained data were subjected to statistical analysis by the technique of analysis of variance (ANOVA) according to Snedecor and Cochran (1982). The treatment means were compared using New Least Significant Difference at $5 \%$ level of probability as mentioned by Waller and Duncan (1969). Economic feasibility of sweet pepper plants production, i.e., gross return, treatment cost, total variable cost, net return and benefit-cost ratio were calculated based on market prices as average of the two seasons. The benefit-cost ratio was determined according to Boardman et al. (2001) by dividing the gross return $\left(L E f^{-1} d^{-1}\right)$ on total variable cost $\left(L E\right.$ fed $\left.{ }^{-1}\right)$.

\section{RESULTS AND DISCUSSION}

\section{Vegetative growth characteristics:}

The present data in Table 2 declare the effect of irrigation levels on vegetative growth characteristics of sweet pepper plants. Such data indicate that the deficit irrigation treatment $\left(1000 \mathrm{~m}^{3} \mathrm{fed}^{-1}\right)$ applied to sweet pepper plants recorded the lowest significant values of vegetative growth characteristics, i.e., stem diameter, relative growth rate, net assimilation rate and leaf relative water content. The highest significant values in this respect were obtained using the highest irrigation water level $\left(2600 \mathrm{~m}^{3} \mathrm{fed}^{-1}\right.$, control). The data are coincided in both seasons of the study. The results are in harmony with those reported by Ezzo et al. (2010) who indicated that the highest plant length, stem diameter, fresh weight, dry weight and root/ shoot ratio of sweet pepper plants were obtained by the high irrigation level $(110 \%$ of $\left.\mathrm{ET}_{0}\right)$.

The negative effects of the lowest irrigation level $\left(1000 \mathrm{~m}^{3} \mathrm{fed}^{-1}\right)$ on sweet pepper plants growth may be related to the drought stress, which affects plant growth by reducing number of leaves and leaf area, resulting in less photosynthesis of sweet pepper plants (Silber, 2005). Moreover, deficit irrigation as a water stress condition eventually reduces plant growth, chlorophyll content, water potential and transpiration rate as well as the free water in plant tissue, leading to deleterious effect on photosynthetic rate, stomatal conductance and intercellular $\mathrm{CO}_{2}$ (Mingchi et al., 2010 on tomato).

The same data demonstrate the effect of foliar application of magnesium carbonate, kaolin and potassium silicate on vegetative growth characteristics of sweet pepper plants. It is clear that foliar applications with kaolin or potassium silicate significantly increased vegetative growth characteristics, i.e., stem diameter, relative growth rate, net assimilation rate 
and leaf relative water content. It is also clear that the lowest significant values in this respect were recorded by the control treatment in both seasons of this work. The significant responses of kaolin foliar application on vegetative growth of sweet pepper plants were confirmed by Creamer et al. (2005) on Chile pepper and Ezzat et al. (2009) on potato. Also, RomeroAranda and Cuartero (2006) found that treating tomato plants with potassium silicate $\left(\mathrm{K}_{2} \mathrm{SiO}_{3}\right)$ as a source of silicon $(2.5 \mathrm{mM})$ improved fresh, dry weight, leaf area and net photosynthesis rates as well as water storage within plant tissues. Furthermore, Abou-Baker et al (2011) indicated that spraying faba bean plants with silicon at $300 \mathrm{ppm}$ as potassium silicate form recorded the highest significant values of plant height, root length, shoot and root dry.

Table 2: Effect of irrigation levels and some foliar applications as well as their interactions on vegetative growth characteristics of sweet pepper plants during 2011 and 2012 seasons

\begin{tabular}{|c|c|c|c|c|c|c|c|c|c|}
\hline \multirow{2}{*}{\multicolumn{2}{|c|}{ Treatments }} & \multicolumn{2}{|c|}{$\begin{array}{l}\text { Stem diameter } \\
(\mathrm{cm})\end{array}$} & \multicolumn{2}{|c|}{$\begin{array}{c}\text { Relative growth } \\
\text { rate } \\
\left(\mathrm{mg} / \mathrm{gm} \mathrm{day}^{-1}\right)\end{array}$} & \multicolumn{2}{|c|}{$\begin{array}{c}\text { Net assimilation } \\
\text { rate } \\
\left(\mathrm{mg} / \mathrm{cm}^{2} \text { day }^{-1}\right)\end{array}$} & \multicolumn{2}{|c|}{$\begin{array}{c}\text { Leaf relative } \\
\text { water content }(\%)\end{array}$} \\
\hline & & $\begin{array}{c}1^{\text {st }} \\
\text { Season }\end{array}$ & $\begin{array}{c}2^{\text {nd }} \\
\text { Season }\end{array}$ & $\begin{array}{c}1^{\text {st }} \\
\text { Season }\end{array}$ & $\begin{array}{c}2^{\text {nd }} \\
\text { Season }\end{array}$ & $\begin{array}{c}1^{\text {st }} \\
\text { Season }\end{array}$ & $\begin{array}{c}2^{\text {nd }} \\
\text { Season }\end{array}$ & $\begin{array}{c}1^{\text {st }} \\
\text { Season }\end{array}$ & $\begin{array}{c}2^{\text {nd }} \\
\text { Season }\end{array}$ \\
\hline \multicolumn{10}{|c|}{ Irrigation levels $\left(\mathrm{m}^{3}\right.$ fed $\left.^{-1}\right)$ : } \\
\hline \multicolumn{2}{|c|}{2600} & 1.78 & 1.80 & 37.97 & 39.50 & 0.384 & 0.431 & 86.18 & 86.97 \\
\hline \multicolumn{2}{|c|}{1800} & 1.70 & 1.65 & 35.69 & 36.71 & 0.358 & 0.407 & 84.84 & 85.92 \\
\hline \multicolumn{2}{|c|}{1000} & 1.39 & 1.33 & 27.82 & 26.69 & 0.283 & 0.306 & 82.37 & 84.28 \\
\hline \multicolumn{2}{|c|}{ New LSD at $5 \%$} & 0.134 & 0.139 & 2.11 & 2.01 & 0.019 & 0.022 & 2.21 & 2.11 \\
\hline \multicolumn{10}{|c|}{ Foliar applications: } \\
\hline \multicolumn{2}{|c|}{ Control $^{*}$} & 1.47 & 1.41 & 28.52 & 28.61 & 0.301 & 0.323 & 82.99 & 83.40 \\
\hline \multicolumn{2}{|c|}{$\mathrm{MgCO}_{3}$} & 1.58 & 1.48 & 33.03 & 31.42 & 0.325 & 0.368 & 83.01 & 85.23 \\
\hline \multicolumn{2}{|c|}{ Kaolin } & 1.71 & 1.71 & 36.19 & 37.94 & 0.365 & 0.413 & 85.25 & 86.45 \\
\hline \multicolumn{2}{|c|}{ K-silicate } & 1.73 & 1.76 & 37.57 & 39.22 & 0.375 & 0.421 & 86.60 & 87.81 \\
\hline \multicolumn{2}{|c|}{ New LSD at $5 \%$} & 0.124 & 0.157 & 2.24 & 1.97 & 0.021 & 0.025 & 2.40 & 2.28 \\
\hline \multicolumn{10}{|c|}{ Irrigation levels $\left(\mathrm{m}^{3} \mathrm{fed}^{-1}\right)$ X Foliar applications: } \\
\hline \multirow{4}{*}{$\begin{array}{l}\text { O } \\
\text { ஸै }\end{array}$} & Control & 1.63 & 1.67 & 33.71 & 31.94 & 0.335 & 0.376 & 85.27 & 84.41 \\
\hline & $\mathrm{MgCO}_{3}$ & 1.75 & 1.73 & 37.12 & 39.14 & 0.373 & 0.418 & 85.32 & 86.93 \\
\hline & Kaolin & 1.84 & 1.87 & 39.75 & 42.60 & 0.410 & 0.458 & 85.89 & 87.44 \\
\hline & K-silicate & 1.91 & 1.94 & 41.31 & 44.32 & 0.418 & 0.471 & 88.23 & 89.10 \\
\hline \multirow{4}{*}{$\begin{array}{l}8 \\
\stackrel{\infty}{-1}\end{array}$} & Control & 1.51 & 1.43 & 28.99 & 26.47 & 0.306 & 0.322 & 83.35 & 83.42 \\
\hline & $\mathrm{MgCO}_{3}$ & 1.69 & 1.49 & 33.47 & 34.11 & 0.321 & 0.401 & 82.36 & 85.39 \\
\hline & Kaolin & 1.81 & 1.79 & 40.71 & 43.58 & 0.399 & 0.455 & 86.31 & 86.99 \\
\hline & K-silicate & 1.79 & 1.87 & 39.59 & 42.66 & 0.407 & 0.451 & 87.35 & 87.88 \\
\hline \multirow{4}{*}{ 용 } & Control & 1.26 & 1.12 & 22.86 & 27.43 & 0.263 & 0.272 & 80.36 & 82.38 \\
\hline & $\mathrm{MgCO}_{3}$ & 1.31 & 1.23 & 28.51 & 21.01 & 0.281 & 0.285 & 81.35 & 83.36 \\
\hline & Kaolin & 1.48 & 1.48 & 28.10 & 27.64 & 0.285 & 0.327 & 83.54 & 84.92 \\
\hline & K-silicate & 1.50 & 1.47 & 31.82 & 30.68 & 0.301 & 0.340 & 84.23 & 86.46 \\
\hline \multicolumn{2}{|c|}{ New LSD at $5 \%$} & 0.134 & 0.167 & 2.32 & 2.08 & 0.020 & 0.023 & 2.37 & 2.12 \\
\hline
\end{tabular}

* Plants sprayed with tap water

Regarding the effect of the interaction between irrigation levels and foliar application of magnesium carbonate, kaolin and potassium silicate on vegetative growth characteristics of sweet pepper plants. Data in Table 2 clearly show that applying the high irrigation water level $\left(2600 \mathrm{~m}^{3} \mathrm{fed}^{-1}\right)$ or the deficit level $\left(1800 \mathrm{~m}^{3} \mathrm{fed}^{-1}\right)$ combined with foliar application of kaolin or potassium silicate had the highest significant stem diameter, relative growth 
rate, net assimilation rate and leaf relative water content. It is also clear that the lowest significant values in this respect were recorded by the lowest irrigation level $\left(1000 \mathrm{~m}^{3} \mathrm{fed}^{-1}\right)$ with no additional foliar antitranspirants or potassium silicate. In addition, foliar application of kaolin or potassium silicate improved all studied growth aspects and leaf relative water content of 1000 $\mathrm{m}^{3}$ fed $^{-1}$ plants relative to $1000 \mathrm{~m}^{3}$ fed $^{-1}$ plants without any foliar antitranspirants or potassium silicate.

The pronounced promotional effect of the foliar application of kaolin and potassium silicate under water stress conditions $\left(1800 \mathrm{~m}^{3} \mathrm{fed}^{-1}\right)$ on vegetative growth characteristics of sweet pepper plants may be related to the direct effects of kaolin on plant resistance to both biotic and abiotic stress including drought (Glenn et al., 2002 and Creamer et al., 2005). In addition, kaolin foliar application was reported to improve $\mathrm{CO}_{2}$ assimilation under high temperature (Glenn et al., 2002). Also, silicon was reported to alleviate water stress by its reduction effect on the diameter of stomatal pores (Efimova and Dokynchan, 1986) that in turn, reduces transpiration rate resulting in reduction in water loss. Another possible action of silicon is the improvement in the efficiency of osmotic adjustment of plant tissues (Romero-Aranda and Cuartero, 2006). Silicon plays a key role in retaining the water capacity of stressed cells, which thereby can tolerate severe drought (Crusciol et al., 2009 on potato). Silicon was reported to enhance rigidity, strengthening and elasticity of cell wall, also silicon promotes plant growth by correcting the levels of endogenous growth hormones, i.e., auxins, gibberellins and cytokinins under stress conditions (Hanafy et al., 2008). Furthermore, potassium silicates as a foliar application provide a supplemental source of potassium. Since potassium has substantial effect on enzyme activation, protein synthesis, photosynthesis, stomatal movement and water-relation (turgor regulation and osmotic adjustment) in plants (Marschner, 1995). Increasing application of $\mathrm{K}^{+}$has been shown to enhance photosynthetic rate, plant growth and yield as well as drought resistance under water stress conditions (Egilla et al., 2001). It was reported also that when $\mathrm{K}^{+}$is deficient, the stomata cannot function properly and water losses from plant may reach damaging levels (Gething, 1990). Such gains can explain the enhancement of plant growth in associated with higher plant water content in sweet pepper plants grown under deficit irrigation condition.

\section{Chemical composition of sweet pepper foliage:}

Data presented in Table 3 are concerning with the effect of irrigation levels on NPK uptake and total chlorophyll contents of sweet pepper plants. It is obvious that increasing irrigation water quantity up to the highest used level $\left(2600 \mathrm{~m}^{3} \mathrm{fed}^{-1}\right)$ significantly increased NPK uptake by plants foliage. Meanwhile, it is clear that total chlorophyll contents in plant leaves reached the highest significant values with the low irrigation level $\left(1000 \mathrm{~m}^{3} \mathrm{fed}^{-1}\right)$, in both seasons of the study. These results were in accordance with those obtained by Sabli (2012) on bell pepper.

The positive effects of increasing irrigation quantities on NPK uptake by sweet pepper plants foliage can be attributed to its enhancing effect on transport of dissolved nutrients by mass flow, because of the higher time- 
averaged water content in the soil (Silber et al., 2005). In addition, the proper balance of moisture in plant creates favorable conditions for photosynthesis and metabolites translocation (Ezzo et al., 2010 on sweet pepper), which accelerate the rate of nutrients uptake. Moreover, sweet pepper plants of the water deficit treatment $\left(1000 \mathrm{~m}^{3} \mathrm{fed}^{-1}\right)$ gave the highest chlorophyll content in leaves, this may be due to the physiological dilution effect of water stress, since such treatment give the lowest relative growth rate, net assimilation rate and leaf relative water content (Table 2).

Table 3: Effect of irrigation levels and some foliar applications as well as their interactions on NPK uptake and total chlorophyll of sweet pepper plants during 2011 and 2012 seasons

\begin{tabular}{|c|c|c|c|c|c|c|c|c|c|}
\hline \multirow{2}{*}{\multicolumn{2}{|c|}{ Treatments }} & \multicolumn{2}{|c|}{$\begin{array}{c}N \text { uptake } \\
\text { (mg/dry plant } \\
\text { foliage) }\end{array}$} & \multicolumn{2}{|c|}{$\begin{array}{c}\text { P uptake } \\
\text { (mg/dry plant } \\
\text { foliage) }\end{array}$} & \multicolumn{2}{|c|}{$\begin{array}{c}\text { K uptake } \\
\text { (mg/dry plant } \\
\text { foliage) }\end{array}$} & \multicolumn{2}{|c|}{$\begin{array}{l}\text { Total chlorophyl } \\
\text { (SPAD unit) }\end{array}$} \\
\hline & & $\begin{array}{c}1^{\text {st }} \\
\text { Season }\end{array}$ & $\begin{array}{c}2^{\text {nd }} \\
\text { Season }\end{array}$ & $\begin{array}{c}1^{\text {st }} \\
\text { Season }\end{array}$ & $\begin{array}{c}2^{\text {nd }} \\
\text { Season }\end{array}$ & $\begin{array}{c}1^{\text {st }} \\
\text { Season }\end{array}$ & $\begin{array}{c}2^{\text {nd }} \\
\text { Season }\end{array}$ & $\begin{array}{c}1^{\text {st }} \\
\text { Season }\end{array}$ & \begin{tabular}{|c|}
$2^{\text {nd }}$ \\
Season
\end{tabular} \\
\hline \multicolumn{10}{|c|}{ Irrigation levels $\left(\mathrm{m}^{3} \mathrm{fed}^{-1}\right.$} \\
\hline \multicolumn{2}{|c|}{2600} & 3389 & 3012 & 295.1 & 265.7 & 4175 & 40 & & 51.46 \\
\hline \multicolumn{2}{|c|}{1800} & 3238 & 2787 & 281.7 & 250.9 & 4023 & & & \\
\hline \multicolumn{2}{|c|}{1000} & 2496 & 2256 & 226.3 & 207.0 & 3247 & & & \\
\hline \multicolumn{2}{|c|}{ New LSD at $5 \%$} & 105.4 & & 31 & 12.81 & 160.3 & & & \\
\hline \multicolumn{10}{|c|}{ Foliar applications: } \\
\hline \multicolumn{2}{|c|}{ Control $^{*}$} & 2759 & 07 & .3 & 2.0 & 3446 & & & \\
\hline \multicolumn{2}{|c|}{$\mathrm{MgCO}_{3}$} & 2851 & 70 & 0.8 & -9.2 & 586 & 1 & & \\
\hline \multicolumn{2}{|c|}{ Kaolin } & 3225 & 787 & 33.4 & 58.1 & 041 & 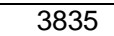 & & \\
\hline \multicolumn{2}{|c|}{ K-silicate } & 328 & 74 & 8.2 & 65.4 & 187 & 48 & & 55.99 \\
\hline \multicolumn{2}{|c|}{ New LSD at $5 \%$} & 111.8 & 103.4 & 16.91 & 14.84 & 52.9 & & & \\
\hline \multicolumn{10}{|c|}{ Irrigation levels $\left(\mathrm{m}^{3} \mathrm{fed}^{-1}\right) \times$ Foliar applications: } \\
\hline \multirow{4}{*}{$\begin{array}{l}\text { : } \\
\text { ㅇ }\end{array}$} & & 3112 & 2941 & 270.5 & 237.1 & 3945 & 3701 & 25 & 48.47 \\
\hline & $\mathrm{M}$ & & 2960 & 275.8 & 252.8 & 3924 & 3911 & & \\
\hline & & 9 & 96 & 303.6 & 77.2 & 4311 & 2 & & \\
\hline & & 95 & 19 & 330.3 & 95.6 & 520 & 5 & 47 & \\
\hline \multirow{4}{*}{\begin{tabular}{l}
$\stackrel{8}{\infty}$ \\
\hdashline
\end{tabular}} & & 89 & 05 & 35.1 & 208.2 & 3503 & 92 & 60 & 54.54 \\
\hline & & 2967 & 2586 & 257.7 & 229.8 & 3644 & 3509 & 58.81 & 56.43 \\
\hline & & 3604 & 3038 & 320.8 & 285.5 & 4460 & 4162 & 61.09 & 57.40 \\
\hline & & 3593 & 3018 & 313.2 & 280.2 & 4485 & 4230 & 78 & 55.60 \\
\hline \multirow{4}{*}{ 음 } & & 2376 & 2075 & 209.3 & 190.7 & 2889 & 2873 & 11 & 57.58 \\
\hline & & 2399 & 2165 & 218.8 & 205.0 & 3191 & 3084 & & 57.60 \\
\hline & & 2513 & 326 & 225.8 & 11.7 & 3351 & 3221 & & \\
\hline & & & & 251.1 & 20.5 & 3557 & & & 58.96 \\
\hline \multicolumn{2}{|c|}{ ew LSD a } & 107.1 & 135.7 & 18.11 & 16.63 & 175.3 & 160.4 & 2.01 & 1.92 \\
\hline
\end{tabular}

* Plants sprayed with tap water

With respect to the effect of the used foliar applications, i.e., magnesium carbonate, kaolin and potassium silicate on NPK uptake and total chlorophyll contents of sweet pepper plants, the same data illustrate that foliar applications with kaolin or potassium silicate significantly increased NPK uptake and total chlorophyll contents in both seasons. The unique exception was that of total chlorophyll which did not show any significant response in the second season of this work. In this respect, foliar application of kaolin was reported to increase chlorophyll contents in Chile pepper leaves (Creamer et al. 2005). 
The positive significant effect of kaolin foliar application on NPK uptake and total chlorophyll contents may be related to its cooling effect as it reduces leaf temperature (Glenn et al., 2002). Although, the shading effect of kaolin film application have been shown to reduce the light available to the leaf by increasing light reflection (Wunsche et al., 2004) and such reduction in light may have negative effect on photosynthesis process, fortunately, this negative impact did not occur here in our case, which suppose that the amount of the reflected light due to kaolin foliar application is neglected or little to cause any reverse effect on photosynthesis process. The results of the relative growth rate and net assimilation rate (Table 2) as affected by kaolin foliar application are greatly confirm this concept. Such conclusion is confirmed by the finding of Glenn et al. (2002). Otherwise, the affirmative effect of potassium silicate on NPK uptake and total chlorophyll contents of sweet pepper plants may be attributed to the effect of silicon on improving photosynthesis activity, which was related with leaf chlorophyll content (Adatia and Besford, 1986). Furthermore, potassium silicate is considered as a rich source of potassium. Since potassium is directly involved in the nutrients absorption through the process of phloem loading as a counter ion to $\mathrm{H}^{+}$(Komor et al., 1980) and so enhancing the mineral content of plant foliage.

As for the effect of interaction between irrigation levels and foliar application of magnesium carbonate, kaolin and potassium silicate on NPK uptake and total chlorophyll contents of sweet pepper plants (Table 3 ). It is obvious clear that applying $2600 \mathrm{~m}^{3}$ fed $^{-1}$ of irrigation water combined with foliar application of potassium silicate and 2600 or $1800 \mathrm{~m}^{3} \mathrm{fed}^{-1}$ of irrigation water combined with foliar application of kaolin or potassium silicate significantly increased NPK uptake. Meanwhile, applying $1000 \mathrm{~m}^{3} \mathrm{fed}^{-1}$ combined with foliar application of kaolin or potassium silicate significantly increased total chlorophyll contents, in both seasons. Similar results were confirmed by Ezzat et al. (2009) who stated that under insufficient water quantity $\left(800 \mathrm{~m}^{3} \mathrm{fed}^{-1}\right)$ foliar application of $4 \%$ kaolin significantly increased photosynthetic pigments, i.e., chlorophyll $\mathrm{a}, \mathrm{b}$ and carotenoids in potato leaves.

\section{Yield characteristics:}

Data of the effect of irrigation levels on yield characteristics and water use efficiency of sweet pepper plants are presented in Table 4. It is obviously clear that increasing water quantity up to $2600 \mathrm{~m}^{3} \mathrm{fed}^{-1}$ led to the highest significant increases in number of fruits per plant, average fruit weight, early and total yield per feddan in comparison to other treatments. However, using the two deficit irrigation treatments (1800 or $1000 \mathrm{~m}^{3} \mathrm{fed}^{-1}$ ) showed the highest values of water use efficiency compared with the high irrigation level, i.e., $2600 \mathrm{~m}^{3} \mathrm{fed}^{-1}$ (control), in both seasons of study. Such results are in line with those of Ezzo et al. (2010) who showed that the highest early yield, total yield, fruit length, fruit diameter and average fruit weight were achieved when pepper plants were irrigated by $110 \%$ of the calculated water requirements. Also, Ismail (2010) observed that deficit irrigation tends to increase water use efficiency and decrease the fresh fruit yield of chili pepper. 
Table 4: Effect of irrigation levels and some foliar applications as well as their interactions on yield characteristics and water use efficiency of sweet pepper plants during 2011 and 2012 seasons

\begin{tabular}{|c|c|c|c|c|c|c|c|c|c|c|c|}
\hline \multirow{2}{*}{\multicolumn{2}{|c|}{ Treatments }} & \multicolumn{2}{|c|}{$\begin{array}{l}\text { No of fruits/ } \\
\text { plant }\end{array}$} & \multicolumn{2}{|c|}{$\begin{array}{l}\text { Average fruit } \\
\text { weight } \\
\text { (g) }\end{array}$} & \multicolumn{2}{|c|}{$\begin{array}{l}\text { Early yield } \\
\left(\text { Ton fed }^{-1}\right)\end{array}$} & \multicolumn{2}{|c|}{$\begin{array}{l}\text { Total yield } \\
\left(\text { Ton fed }^{-1}\right)\end{array}$} & \multicolumn{2}{|c|}{$\begin{array}{l}\text { Water use } \\
\text { efficiency } \\
\left(\mathbf{k g} / \mathrm{m}^{3}\right)\end{array}$} \\
\hline & & \begin{tabular}{|c|}
$1^{\text {st }}$ \\
Season \\
\end{tabular} & \begin{tabular}{|c|}
$2^{\text {nd }}$ \\
Season \\
\end{tabular} & \begin{tabular}{|c|}
$1^{\text {st }}$ \\
Season
\end{tabular} & \begin{tabular}{|c|}
$2^{\text {nd }}$ \\
Season \\
\end{tabular} & \begin{tabular}{|c|}
$1^{\text {st }}$ \\
Season
\end{tabular} & \begin{tabular}{|c|}
$2^{\text {nd }}$ \\
Season \\
\end{tabular} & $\begin{array}{c}1^{\text {st }} \\
\text { Season }\end{array}$ & \begin{tabular}{|c|}
$2^{\text {nd }}$ \\
Season \\
\end{tabular} & \begin{tabular}{|c|}
$1^{\text {st }}$ \\
Season \\
\end{tabular} & $\begin{array}{c}2^{\text {nd }} \\
\text { Season }\end{array}$ \\
\hline \multicolumn{12}{|c|}{ Irrigation levels $\left(\mathrm{m}^{3} \mathrm{fed}^{-1}\right)$ : } \\
\hline \multicolumn{2}{|c|}{2600} & \begin{tabular}{|l|}
16.40 \\
\end{tabular} & 15.91 & 89.74 & 99.03 & 2.58 & 2.38 & 14.72 & 15.76 & 3.07 & 3.28 \\
\hline \multicolumn{2}{|c|}{1800} & 16.10 & 15.67 & 86.41 & 95.88 & 2.50 & 2.30 & 13.98 & 15.09 & 3.89 & 4.19 \\
\hline \multicolumn{2}{|c|}{1000} & 14.17 & 13.44 & 65.98 & 71.11 & 2.21 & 1.99 & 9.37 & 9.57 & 3.91 & 3.99 \\
\hline \multirow{2}{*}{\multicolumn{2}{|c|}{\begin{tabular}{|c|} 
New LSD at $5 \%$ \\
Foliar applica
\end{tabular}}} & 0.341 & 0.233 & 2.34 & 3.07 & 0.071 & 0.061 & 0.448 & 0.442 & 0.191 & 0.176 \\
\hline & & ations: & & & & & & & & & \\
\hline \multicolumn{2}{|c|}{ Control $^{\star}$} & 14.46 & 14.28 & 77.26 & 83.73 & 2.28 & 2.11 & 1.28 & 12.08 & 3.19 & 3.41 \\
\hline \multicolumn{2}{|c|}{$\mathrm{MgCO}_{3}$} & 15.05 & 14.54 & 78.72 & 87.41 & 2.38 & 2.18 & 11.92 & 12.82 & 3.41 & 3.64 \\
\hline \multicolumn{2}{|c|}{ Kaolin } & 16.47 & 15.74 & 84.19 & 92.36 & 2.56 & 2.32 & 13.99 & 14.70 & 4.01 & 4.19 \\
\hline \multicolumn{2}{|c|}{ K-silicate } & 16.25 & 15.46 & 82.65 & 91.19 & 2.50 & 2.28 & 13.56 & 14.28 & 3.86 & 4.05 \\
\hline \multirow{2}{*}{\multicolumn{2}{|c|}{\begin{tabular}{|c|} 
New LSD at $5 \%$ \\
Irrigation leve
\end{tabular}}} & 0.412 & 0.351 & 2.56 & 2.84 & 0.084 & 0.074 & 0.431 & 0.457 & 0.186 & 0.180 \\
\hline & & \multicolumn{10}{|c|}{ Irrigation levels $\left(\mathrm{m}^{3} \mathrm{fed}^{-1}\right)$ X Foliar applications: } \\
\hline \multirow{4}{*}{ ¿্口 } & Control & 15.80 & 15.50 & 88.92 & 97.04 & 2.53 & 2.31 & 14.05 & 15.04 & 2.93 & 3.13 \\
\hline & $\mathrm{MgCO}_{3}$ & 15.97 & 15.47 & 89.15 & 99.39 & 2.58 & 2.39 & 14.24 & 15.38 & 2.97 & 3.20 \\
\hline & Kaolin & 16.97 & 16.36 & 90.35 & 100.1 & 2.64 & 2.42 & 15.33 & 16.38 & 3.19 & 3.41 \\
\hline & K-silicate & 16.87 & 16.29 & 90.53 & 99.57 & 2.62 & 2.41 & 15.27 & 16.22 & 3.18 & 3.38 \\
\hline \multirow{4}{*}{$\begin{array}{l}\text { 이 } \\
\infty \\
-\end{array}$} & Control & 14.43 & 14.24 & 80.26 & 88.24 & 2.26 & 2.08 & 11.58 & 12.57 & 3.22 & 3.49 \\
\hline & $\mathrm{MgCO}_{3}$ & 15.03 & 14.86 & 82.10 & 91.98 & 2.35 & 2.18 & 12.34 & 13.67 & 3.43 & 3.80 \\
\hline & Kaolin & 17.64 & 16.92 & 92.32 & 102.5 & 2.71 & 2.49 & 16.29 & 17.34 & 4.53 & 4.82 \\
\hline & K-silicate & 17.28 & 16.64 & 90.94 & 100.8 & 2.63 & 2.43 & 15.71 & 16.77 & 4.36 & 4.66 \\
\hline \multirow{4}{*}{ 음 } & Control & 13.14 & 13.09 & 62.59 & 65.90 & 2.05 & 1.93 & 8.22 & 8.63 & 3.43 & 3.60 \\
\hline & $\mathrm{MgCO}_{3}$ & 14.16 & 13.29 & 64.92 & 70.86 & 2.21 & 1.96 & 9.19 & 9.42 & 3.83 & 3.93 \\
\hline & Kaolin & 14.79 & 13.93 & 69.91 & \begin{tabular}{|l|}
74.48 \\
\end{tabular} & 2.31 & 2.06 & 10.34 & 10.38 & 4.31 & 4.33 \\
\hline & K-silicate & 14.60 & 13.46 & 66.48 & 73.20 & 2.28 & 1.99 & 9.71 & 9.85 & 4.05 & 4.10 \\
\hline \multicolumn{2}{|c|}{ New LSD at $5 \%$} & 0.419 & 0.390 & 2.55 & 2.96 & 0.097 & 0.089 & 0.593 & \begin{tabular}{|l|}
0.574 \\
\end{tabular} & 0.208 & \begin{tabular}{|l|}
0.269 \\
\end{tabular} \\
\hline
\end{tabular}

Concerning the effect of the used foliar applications, i.e., magnesium carbonate, kaolin and potassium silicate on yield characteristics and water use efficiency of sweet pepper plants. The same data clearly reveal that foliar applications of kaolin or potassium silicate had the highest significant number of fruits per plant, average fruit weight, early and total yield per feddan as well as water use efficiency compared to foliar application of magnesium carbonate and control, in both seasons. The obtained results are in line with those of Glenn et al. (2002) who observed that foliar applications of kaolin was corresponded by the remarkable improve in water use efficiency by apple plants. On the other hand, Romero-Aranda and Cuartero (2006) reported that treating tomato plants with potassium silicate $(2.5 \mathrm{mM} \mathrm{Si}$, as $\mathrm{K}_{2} \mathrm{SiO}_{3}$ ) enhanced water use efficiency by $17 \%$. Such results were confirmed also by the findings of Abou-Baker et al. (2011) on faba bean plants.

Regarding the effect of the interaction between irrigation levels and foliar application of magnesium carbonate, kaolin and potassium silicate on yield characteristics and water use efficiency of sweet pepper plants. It is 
obviously clear that number of fruits per plant, average fruit weight, early and total yield per feddan as well as water use efficiency were significantly affected by applying $1800 \mathrm{~m}^{3} \mathrm{fed}^{-1}$ of irrigation water combined with foliar application of kaolin or potassium silicate followed by applying $2600 \mathrm{~m}^{3} \mathrm{fed}^{-1}$ (control) combined with foliar application of kaolin or potassium silicate. These results had the same trend during the two seasons. In this respect, Srinivasa Rao (1985) reported that under deficit irrigation conditions, a single spray of $5 \%$ kaolin improved the water status and yield of tomato plants compared with control plants. Such results also are in line with those of Creamer et al. (2005) on Chile pepper. On the other hand, Crusciol et al. (2009) stated that silicon application under drought stress conditions increased potato yield.

It is clear that foliar application of potassium silicate or kaolin tended to increase average fruit weight, early and total yield of sweet pepper fruits as well as water use efficiency under the deficit irrigation level $\left(1800 \mathrm{~m}^{3} \mathrm{fed}^{-1}\right)$. This result could be explained on the basis that such treatment showed the pronounced positive effects on the vegetative growth aspects (Table 2), NPK uptake and chlorophyll content (Table 3) leading to healthy sweet pepper plants and hence increasing yield aspects.

\section{Fruit quality characteristics:}

Data listed in Table 5 show the effect of irrigation levels on fruit quality characteristics of sweet pepper plants. It is clear that increasing water quantity applied to sweet pepper plants up to the highest level $\left(2600 \mathrm{~m}^{3} \mathrm{fed}^{-1}\right)$ resulted in the highest significant increase in fruit flesh thickness. On the other hand, the deficit irrigation treatments (1800 or $\left.1000 \mathrm{~m}^{3} \mathrm{fed}^{-1}\right)$ showed the highest values of vitamin $\mathrm{C}$, total soluble solids, reducing sugars and total sugars in sweet pepper fruits. These results had the same trend in both growing seasons. The results are coincided with those of Ezzo et al. (2010) who indicated that the highest significant values of total soluble solids were recorded with the lowest water levels while the lowest values were recorded with the highest water level. Moreover, Mingchi et al. (2010) demonstrated that drought stress improved tomato fruit quality, i.e., acidity, vitamin $C$ and sugar/acid ratio.

Since Sweet pepper fruits with higher sugars have a more acceptable flavor, such character are considered as one of the important quality aspect. Water stress was reported to increase the levels of soluble sugars (glucose, sucrose, sorbitol, galactose, etc.) and total soluble proteins (Abdalla and ElKhoshiban, 2007). Therefore, the stimulatory effect of deficit irrigation on fruit quality aspects of sweet pepper may be explained by a decrease in water accumulation by the fruit without any significant modification in the quantity of the accumulated sugars (Guichard et al., 1999).

Concerning the effect of foliar application of magnesium carbonate, kaolin and potassium silicate applications on fruit quality characteristics of sweet pepper plants. The same data clearly reveal that foliar application of potassium silicate resulted in the highest significant values of fruit flesh thickness. Meanwhile, foliar applications of kaolin or potassium silicate tended to increase vitamin C, total soluble solids, reducing sugars and total 
sugars contents in pepper fruits, in both seasons of this work. The exception was that of vitamin $\mathrm{C}$ in the first season and total sugars in the second season which did not show any significant response. These results were in conformity with those obtained by Lynch (2008) who found that silicon increased the level of sucrose and water-soluble carbohydrates in grapes and banana.

Table 5: Effect of irrigation levels and some foliar applications as well as their interactions on fruit quality characteristics of sweet pepper plants during 2011 and 2012 seasons

\begin{tabular}{|c|c|c|c|c|c|c|c|c|c|c|c|}
\hline \multirow{2}{*}{\multicolumn{2}{|c|}{ Treatments }} & \multicolumn{2}{|c|}{$\begin{array}{c}\text { Fruit flesh } \\
\text { thickness } \\
(\mathrm{mm})\end{array}$} & \multicolumn{2}{|c|}{$\begin{array}{c}\text { Vit. C } \\
\text { (mg } 100 \text { gm } \\
\text { FW) }\end{array}$} & \multicolumn{2}{|c|}{$\begin{array}{l}\text { TSS } \\
(\%)\end{array}$} & \multicolumn{2}{|c|}{$\begin{array}{l}\text { Reducing } \\
\text { sugars } \\
\text { (mg g-1 DW) }\end{array}$} & \multicolumn{2}{|c|}{$\begin{array}{l}\text { Total sugars } \\
\left(\mathrm{mg} \mathrm{g}^{-1} \mathrm{DW}\right)\end{array}$} \\
\hline & & \begin{tabular}{|c}
$1^{\text {st }}$ \\
Season
\end{tabular} & $\begin{array}{c}2^{\text {nd }} \\
\text { Season }\end{array}$ & $\begin{array}{c}1^{\text {st }} \\
\text { Season }\end{array}$ & $\begin{array}{c}2^{\text {nd }} \\
\text { Season }\end{array}$ & $\begin{array}{c}1^{\text {st }} \\
\text { Season }\end{array}$ & $\begin{array}{c}2^{\text {nd }} \\
\text { Season }\end{array}$ & $\begin{array}{c}1^{\text {st }} \\
\text { Season }\end{array}$ & $\begin{array}{c}2^{\text {nd }} \\
\text { Season }\end{array}$ & $\begin{array}{c}1^{\text {st }} \\
\text { Season }\end{array}$ & $\begin{array}{c}2^{\text {nd }} \\
\text { Season }\end{array}$ \\
\hline \multicolumn{12}{|c|}{ Irrigation levels $\left(\mathrm{m}^{3} \mathrm{fed}^{-1}\right)$ : } \\
\hline \multicolumn{2}{|c|}{2600} & 4.54 & 4.68 & 105.5 & 102.4 & 5.22 & 5.40 & 10.68 & 10.61 & 30.47 & 30.71 \\
\hline \multicolumn{2}{|c|}{1800} & 4.34 & 4.42 & 112.4 & 112.0 & 5.51 & 5.96 & 11.33 & 11.74 & 34.77 & 34.47 \\
\hline \multicolumn{2}{|c|}{1000} & 3.95 & 3.97 & 113.4 & 112.5 & 5.57 & 5.94 & 11.50 & 11.75 & 35.74 & 35.87 \\
\hline \multicolumn{2}{|c|}{ New LSD 5\% } & 0.171 & 0.211 & 2.84 & 2.97 & 0.157 & 0.187 & 0.192 & 0.247 & 1.12 & \\
\hline \multicolumn{12}{|c|}{ Foliar applications: } \\
\hline \multicolumn{2}{|c|}{ Control* $^{*}$} & 4.13 & 4.16 & 107.9 & 104.9 & 5.31 & 5.53 & 10.81 & 10.84 & 32.47 & 31.88 \\
\hline \multicolumn{2}{|c|}{$\mathrm{MgCO}_{3}$} & 4.17 & 4.27 & 109.5 & 106.7 & 5.34 & 5.69 & 11.05 & 11.20 & 33.31 & 33.57 \\
\hline \multicolumn{2}{|c|}{ Kaolin } & 4.48 & 4.63 & 112.8 & 112.6 & 5.56 & 5.93 & 11.44 & 11.67 & 34.92 & 34.84 \\
\hline \multicolumn{2}{|c|}{ K-silicate } & 4.32 & 4.38 & 111.5 & 111.6 & 5.52 & 5.92 & 11.38 & 11.76 & 33.93 & 34.43 \\
\hline \multicolumn{2}{|c|}{ New LSD 5\% } & 0.154 & 0.236 & NS & 2.87 & 0.161 & 0.197 & 0.184 & 0.235 & 09 & IS \\
\hline \multicolumn{12}{|c|}{ Irrigation levels $\left(\mathrm{m}^{3} \mathrm{fed}^{-1}\right) \mathrm{X}$ Foliar applications: } \\
\hline \multirow{4}{*}{$\begin{array}{l}\text { ㅇ } \\
\stackrel{Ð}{N}\end{array}$} & Control & 4.45 & 4.49 & 102.4 & 99.12 & 5.04 & 5.27 & 10.08 & 10.19 & 29.26 & 28.28 \\
\hline & $\mathrm{MgCO}_{3}$ & 4.47 & 4.61 & 104.3 & 99.73 & 5.13 & 5.34 & 10.57 & 10.54 & 30.02 & 31.44 \\
\hline & Kaolin & 4.68 & 4.86 & 108.5 & 107.7 & 5.36 & 5.47 & 11.04 & 10.79 & 32.36 & 32.30 \\
\hline & K-silicate & 4.58 & 4.75 & 106.8 & 102.9 & 5.34 & 5.53 & 11.02 & 10.91 & 30.25 & 30 \\
\hline \multirow{4}{*}{$\begin{array}{l}8 \\
\infty \\
\infty\end{array}$} & Control & 4.15 & 4.21 & 109.9 & 107.2 & 5.41 & 5.70 & 11.04 & 11.25 & 33.40 & 32.06 \\
\hline & $\mathrm{MgCO}_{3}$ & 4.22 & 4.36 & 111.9 & 110.9 & 5.38 & 5.92 & \begin{tabular}{|l|}
11.20 \\
\end{tabular} & 11.58 & 34.22 & 33.86 \\
\hline & Kaolin & 4.57 & 4.70 & 114.1 & 114.1 & 5.62 & 6.15 & 11.57 & 11.98 & 35.92 & 36.00 \\
\hline & K-silicate & 4.42 & 4.42 & 113.5 & 115.7 & 5.63 & 6.07 & 11.51 & 12.16 & 35.52 & 35.96 \\
\hline \multirow{4}{*}{ 음 } & Control & 3.80 & 3.77 & 111.5 & 108.5 & 5.49 & 5.61 & 11.31 & 11.07 & 34.75 & 35.31 \\
\hline & $\mathrm{MgCO}_{3}$ & 3.82 & 3.83 & 112.2 & 109.4 & 5.51 & 5.82 & 11.37 & 11.49 & 35.68 & 35.42 \\
\hline & Kaolin & 4.18 & 4.33 & 115.7 & 115.9 & 5.69 & 6.18 & 11.72 & 12.23 & 36.49 & 36.21 \\
\hline & K-silicate & 3.98 & 3.96 & 114.3 & 116.2 & 5.59 & 6.16 & 11.60 & 12.20 & 36.03 & 36.52 \\
\hline \multicolumn{2}{|c|}{ New LSD 5\% } & 0.181 & 0.223 & 3.16 & 3.04 & 0.174 & 0.191 & 0.201 & 0.269 & 1.24 & 1.10 \\
\hline
\end{tabular}

The positive significant effect of potassium silicate on the quality aspects of sweet pepper fruits in comparison with the other treatments may be attributed to the significant absorption of NPK nutrients (Table 3). In addition, potassium silicate is conceder as significant supplement of $\mathrm{K}$, since potassium plays an important role in water status of plant, promoting the translocation of newly synthesized photosynthetics and mobilization of metabolites as well as promoting the synthesis of sugars and polysaccharides (Mengel and Kirkby, 1982). 
With respect to the effect of the interaction on fruit quality characteristics of sweet pepper plants, the same data illustrate that fruit flesh thickness was significantly increased by applying $2600 \mathrm{~m}^{3} \mathrm{fed}^{-1}$ of irrigation water combined with kaolin or potassium silicate foliar application. On the other hand, vitamin $\mathrm{C}$, total soluble solids, reducing sugars and total sugars contents recorded the highest significant values using the deficit irrigation treatments (1800 or $1000 \mathrm{~m}^{3} \mathrm{fed}^{-1}$ ) combined with foliar application of kaolin or potassium silicate, during both seasons of the study. The results are coincided with those of Ezzat et al. (2009) who indicated that under insufficient water quantity, treating potato plants with kaolin as a foliar application at $4 \%$ improved tuber quality.

\section{Economic feasibility:}

The economic feasibility of cultivation sweet pepper plants as affected by irrigation levels, magnesium carbonate, kaolin and potassium silicate applications are presented in Table 6 . The results showed that the highest net return (15185 $\mathrm{LE} \mathrm{fed}^{-1}$ ) was obtained under the irrigation with $1800 \mathrm{~m}^{3}$ fed $^{-1}$ combined with foliar application of kaolin; such treatment returns the highest benefit-cost ratio (2.51) in comparison with the other treatments. Therefore, this treatment considered to be economical for sweet pepper production under the conditions of the present study.

Table 6: Economic feasibility of sweet pepper production as affected by irrigation levels and some foliar applications during 2011 and 2012 seasons

\begin{tabular}{|c|c|c|c|c|c|c|c|c|}
\hline \multicolumn{2}{|c|}{ Treatments } & $\begin{array}{l}\text { Total yield } \\
\left(\text { Ton fed }^{-1}\right)^{(1)}\end{array}$ & $\begin{array}{c}\text { Gross } \\
\text { return } \\
\left(\text { LE fed }^{-1}\right)^{(2)}\end{array}$ & 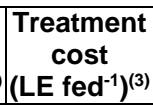 & \begin{tabular}{|c} 
Total \\
variable cost \\
$\left(\text { LE fed }^{-1}\right)^{(4)}$
\end{tabular} & $\begin{array}{l}\text { Net return } \\
\left(\text { LE fed }^{-1}\right)^{(5)}\end{array}$ & $\begin{array}{c}\text { Benefit } \\
\text { cost ratio }^{(6)}\end{array}$ & Order \\
\hline \multirow{4}{*}{$\begin{array}{l}\text { ○् } \\
\text { ஸ్ }\end{array}$} & Control & 14.55 & 21825 & 1095 & 9890 & 11935 & 2.21 & 5 \\
\hline & $\mathrm{MgCO}_{3}$ & 14.81 & 22215 & 1695 & 10490 & 11725 & 2.12 & 6 \\
\hline & Kaolin & 15.86 & 23790 & 1615 & 10410 & 13380 & 2.29 & 3 \\
\hline & K-silicate & 15.75 & 23625 & 1595 & 10390 & 13235 & 2.27 & 4 \\
\hline \multirow{4}{*}{ ○ } & Control & 12.08 & 18120 & 730 & 9525 & 8595 & 1.90 & 8 \\
\hline & $\mathrm{MgCO}_{3}$ & 13.01 & 19515 & 1330 & 10125 & 9390 & 1.93 & 7 \\
\hline & Kaolin & 16.82 & 25230 & 1250 & 10045 & 15185 & 2.51 & 1 \\
\hline & K-silicate & 16.24 & 24360 & 1230 & 10025 & 14335 & 2.43 & 2 \\
\hline \multirow{4}{*}{ 응 } & Control & 8.43 & 12645 & 548 & 9343 & 3302 & 1.35 & 12 \\
\hline & $\mathrm{MgCO}_{3}$ & 9.31 & 13965 & 1148 & 9943 & 4022 & 1.40 & 11 \\
\hline & Kaolin & 10.36 & 15540 & 1068 & 9863 & 5677 & 1.58 & 9 \\
\hline & K-silicate & 9.78 & 14670 & 1048 & 9843 & 4827 & 1.49 & 10 \\
\hline
\end{tabular}

(1) Sweet pepper total yield as average of two seasons. (2) Gross return as total yield (ton fed ${ }^{-1}$ $x 1500 \mathrm{LE} \mathrm{ton}^{-1}$. (3) Treatment cost was calculated according to the following prices: Magnesium carbonate $25 \mathrm{LE} \mathrm{kg}^{-1}$; Kaolin $=20 \mathrm{LE} \mathrm{kg}^{-1}$; Potassium silicate $=50 \mathrm{LE} \mathrm{kg}^{-1}$. (4) Total variable cost (LE fed ${ }^{-1}$ ) include: Treatment cost plus land leasehold, transplants, N, P and K fertilizers, microelements, pesticides, labors and other cultural practices which equal nearly $8795 \mathrm{LE} \mathrm{fed}^{-1}$. (5) $=(2)-(4) \cdot(6)=(2) /(4)$.

Finally, this investigation imply that irrigation sweet pepper plants with $1800 \mathrm{~m}^{3} \mathrm{fed}^{-1}$ combined with foliar application of kaolin (4\%, 4 times during the season) could be recommended to improve the vegetative growth characteristics, chemical composition, total yield, water use efficiency and fruit quality, saving about $25 \%$ of the total used irrigation water quantity in 
sweet pepper production. Such treatment can be recommended under drip irrigation system in clay-loam soil at northern of Nil Delta lands, giving the highest net return and benefit-cost ratio to the farmers.

\section{REFERENCES}

Abd El-Aal, F. S.; M. M. Abd El-Mouty and A. H. Ali (2008). Combined effect of irrigation intervals and foliar application of some antitranspirants on eggplant growth, fruits yield and its physical and chemical properties. Res. J. Agric. and Biol. Sci., 4(5): 416-423.

Abdalla, M. M. and N. H. El-Khoshiban (2007). The influence of water stress on growth, relative water content, photosynthetic pigments, some metabolic and hormonal contents of two Triticum aestivum cultivars. J. Applied Sci. Res., 3(12): 2062- 2074.

Abou-Baker, A. H.; M. Abd-Eladl and M. M. Abbas (2011). Use of silicate and different cultivation practices in alleviating salt stress effect on bean plants. Australian J. Basic and Applied Sci., 5(9):769-781 .

Adatia, M. H. and R. T. Besford (1986). The effects of silicon on cucumber plants grown in recirculating nutrient solution. Ann. Bot. London, 58:343-51.

AOAC (1990). Official Methods of Analysis of the Association of Official Edition, Washington, D. C.

Begg, J. E. and N. C. Turner (1976). Crop water deficits. Advances in Agron., 28, pp.189.

Boardman, A. E.; D. H. Greenberg; A. R. Vining and D. L. Weimer (2001). Cost-benefit analysis. Concepts and practice. $2^{\text {nd }}$ Ed. Prentice Hall, Upper Saddle River.

Bremner, J. M. and C. S. Mulvaney (1982). Total nitrogen. In: Page, A. L., R. H. Miller and D. R. Keeney (eds.) Methods of Soil Analysis. Part 2, Amer. Soc. Agron. Madison, W. I. USA, 595- 624.

Creamer, R.; S. Sanogo and O. A. El-Sebai (2005). Kaolin-based foliar reflectant affects physiology and incidence of beet curly top virus but not yield of Chile pepper. Hortscince, 40(3):574-576.

Crusciol, C. A. C.; A. L. Pulz; L. B. Lemos; R. P. Soratto and G. P. P. Lima (2009). Effects of silicon and drought stress on tuber yield and leaf biochemical characteristics in potato. Crop Physiology and Metabolism, 49: 949-954.

Efimova, G. V. and S. A. Dokynchan (1986). Anatomo-morphological construction of epidermal tissue of rice leaves and increasing of its protection function under silicon effect. Agric. Biol., 3:57-61.

Egilla, J.N.; Davies, F.T. Jr. and Drew, M.C. 2001. Effect of potassium on drought resistance of Hibiscus rosa-sinensis cv. Leprechaun: Plant growth, leaf macro and micronutrient content and root longevity. Plant and Soil 229(2): 213-224.

Ezzat, A. S.; U. M. Saif El-deen and A. M. Abd El-Hameed (2009). Effect of irrigation water quantity, antitranspirant and humic acid on growth, 
yield, nutrients content and water use efficiency of potato (Solanum tuberosum L.). J. Agric. Sci., Mansoura Univ., 34(12):11585-11603.

Ezzo, M; A. A. Glala; H. A. M Habib and A. A. Helaly (2010). Response of sweet pepper grown in sandy and clay soil lysimeters to water regimes. American-Eurasian J. Agric. \& Environ. Sci., 8 (1): 18-26.

Gardner, F.; R. Pearce and R. L. Mitchell (1985). Physiology of crop plants. lowa State University Press, Ames, USA, pp. 66.

Gething, P. A. (1990). Potassium and water relationships. In: Potash facts. IPI. Bern.

Glenn, D. M.; E. Prado; A. Erez; J. McFerson and G. J. Puterka (2002). A reflective, processed-kaolin particle film affects fruit temperature, radiation reflection, and solar injury in apple. J. Amer. Soc. Hort. Sci., 127:188-193.

Guichard, S.; C. Gary; J. J. Longuenesse and C. Leonardi (1999). Water fluxes and growth of greenhouse tomato fruits under summer conditions. Acta Hort., 507: 223-230.

Hanafy, A. H.; E. M. Harb, M. A. Higazy and S. H. Morgan (2008). Effect of silicon and boron foliar applications on wheat plants grown under saline soil conditions. International J. Agric. Res., 3(1): 1-26.

Hoffman, G. J., Towell, T. A. and Solomon, K. H. (1990). Management of farm irrigation systems, ASAE, St. Joseph, MI, USA.

Hunt, R. (1990). Basic growth analysis: Plant growth analysis for beginners. Unwin Hyman, London. pp.112.

Ismail, S. M. (2010). Influence of deficit irrigation on water use efficiency and bird pepper production (Capsicum annuum L.). JKAU: Met., Env. \& Arid Land Agric. Sci., 21(2): 29-43.

Jackson, M. L. (1973). Soil chemical analysis. Prentic-Hall, India, 144-197.

Kahn, B. A. and J. P. Damicone (2008). Kaolin particle film product applications before harvest begins may not improve marketable yields of fresh tomatoes. Hort. Technology, 18(1): 144-147.

Koller, H. R. (1972). Leaf area-leaf weight relationship in soybean canopy. Crop. Sci., 12:180-183.

Komor, E.; M. Rotter; J. Waldhauser; E. Martin, and B. H. Cho, (1980). Sucrase proton symport for phloem loading in the ricinus seedlings. Ber. Deutsh. Bot. Ges., 93: 211-219.

Lynch, M. 2008. Silicates in contemporary Australian farming: a 20-year review. Silicon in Agriculture $4^{\text {th }}$ International Conference Port Edward, South Africa. P. 68.

Marschner, H. (1995). Mineral Nutrition of Higher Plants. $2^{\text {nd }}$ Ed. Academic Press, San Diego, California, USA.

Mengel, K. and E. A. Kirkby (1982). Textbook of principles of plant nutrition. $3^{\text {rd }}$ ed. P. 655. International Potash Institute, Bern, Switzerland.

Mingchi, L.; L. Xiangli; H. Jing and G. Lihong (2010). Effect of simulated drought stress on plant growth, yield and fruit properties of tomato. Acta Hort., 856:193-202.

Murquard, R. D. and J. L. Timpton (1987). Relationship between extractable chlorophyll and an insitu method to estimate leaf green. Hort. Sci., 22(6): 1327. 
Olsen, S. R. and L. E. Sommers (1982). Phosphorus. In: Page, A. L.; R. H. Miller and D. R. Keeney (Eds). Methods of soil analysis. Part 2 Amer. Soc. Agron. Madison, W. I. USA, pp. 403-430.

Page, A. L. (1982). Methods of Soil Analysis. $2^{\text {nd }}$ ed., Part 1, Soil Sci. Soc. Amer., Madison, Wisc., USA.

Romero-Aranda, M. R. and O. J. J. Cuartero (2006). Silicon alleviates the deleterious salt effect on tomato plant growth by improving plant water status. J. Plant Physi., 163: 847-855.

Sabli, M. Z. (2012). Fertigation of bell pepper (Capsicum annuum L.) in a soilless greenhouse system: Effects of fertilizer formulation and irrigation frequency. PhD thesis, Newcastle University, United Kingdom., p.243.

Sadasivam, S. and A. Manickam (1992). Biochemical methods. New Delhi: Wiley Eastern Limited. pp.187.

Sen, S.; A. Bhattacharya; D. Mazumder; H. Sen; A. K. Das and S. Pal (2005). Nutrient and antinutrient composition of cormels of colocasia esculenta var antiquorum, J. Veg. Sci., 11:17-34.

Silber, A. (2005). Fertigation frequency and nutrient uptake by plants: benefits and constraints. Proceedings No. 571, International Fertiliser Society, York, UK, pp.36.

Silber, A., M. Bruner and E. Kenig (2005). High fertigation frequency and phosphorus level: Effects on summer-grown bell pepper grown and blossom end rot incidence. Plant and Soil, 270:135-146.

Snedecor, G. W. and W. G. Cochran. (1982). Statistical Methods. $7^{\text {th }}$ ed. $2^{\text {nd }}$ printing, lowa State. Univ. Press, Ame., USA, pp. 507.

Turner, N. C. (1981). Techniques and experimental approaches for the measurement of plant water stress. Plant Soil, 58:339-366.

Waller, R. A. and D. B. Duncan (1969). A bayes for the symmetric multiple comparison problem. J. Amer. Stat. Assoc., 64:1484-1503.

Wunsche, J. N.; L. Lombardini and D. H. Greer (2004). Surround particle film applications effects on whole canopy physiology of apple. Acta Hort., 636:565-571. 


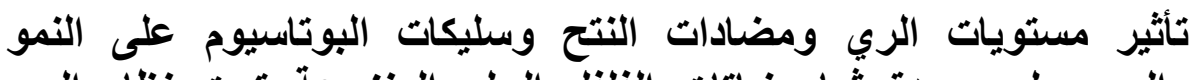

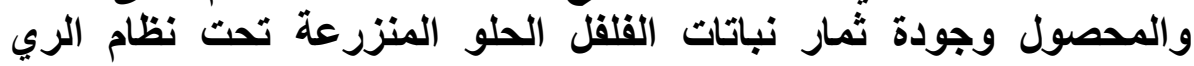

\author{
بالتنقيط \\ أحمد مصطفى كمال \\ قسم بحوث الخضر -معهر بحوث البساتين-مركز البحوث الزراعية_الجيزة مصر
}

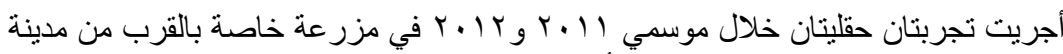

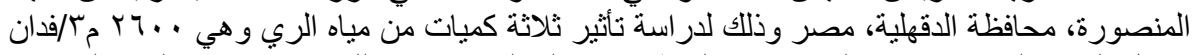

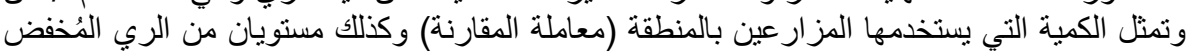

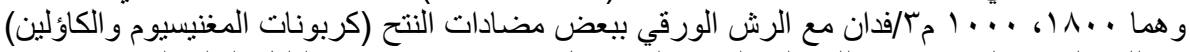

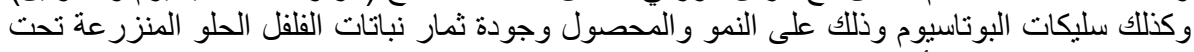

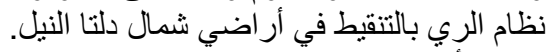

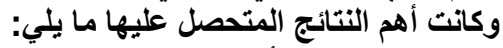

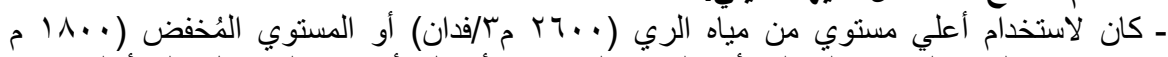

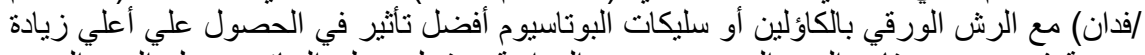

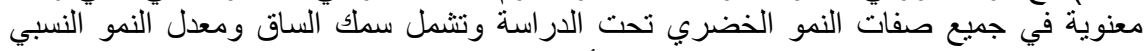

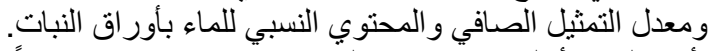

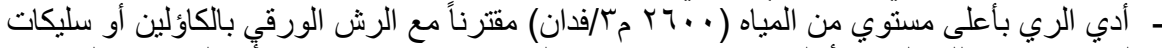

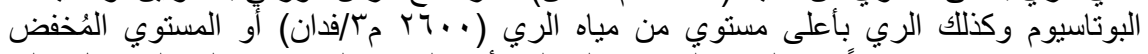

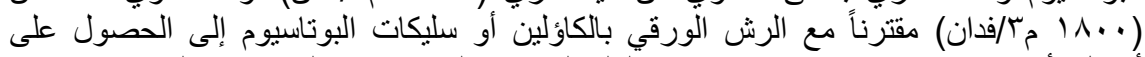

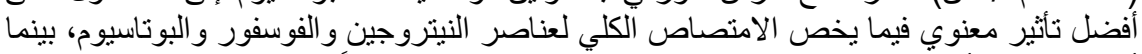

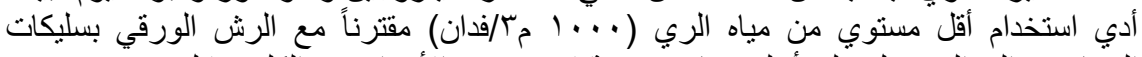

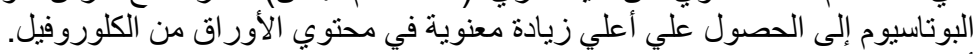

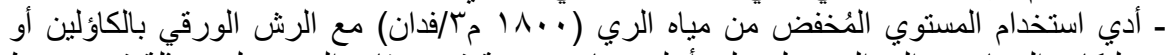

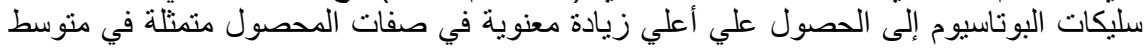
وزن الثمرة والمحصول المبكر وكذلك المحصول الكلي للفدات وكذلك كفاءة استخدام المياه بواسطة

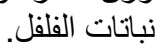

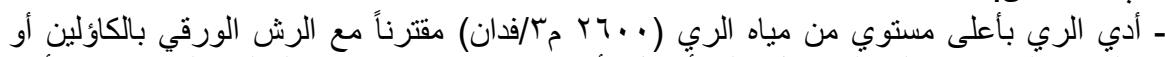

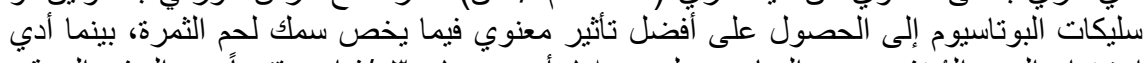

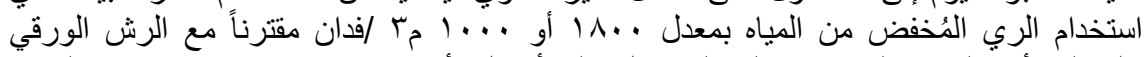

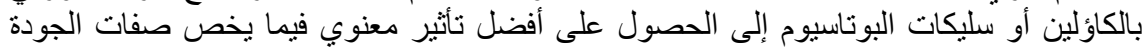

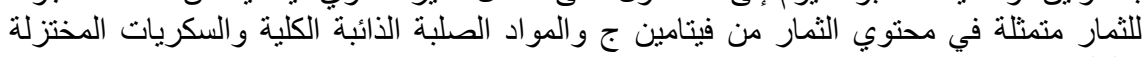
و الكلية.

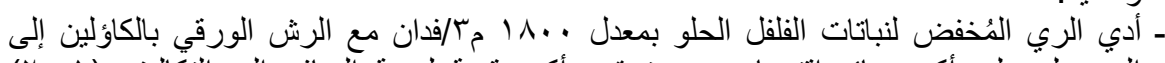

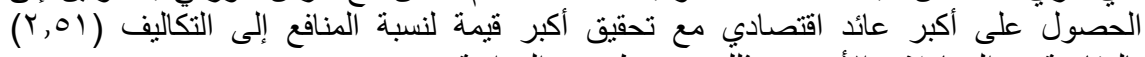

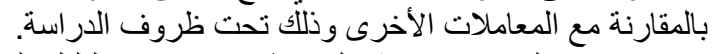

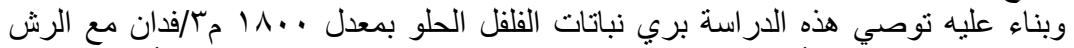

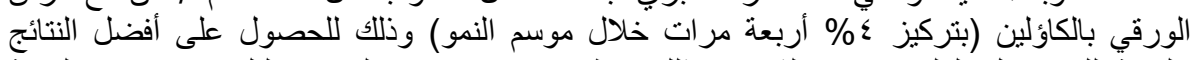

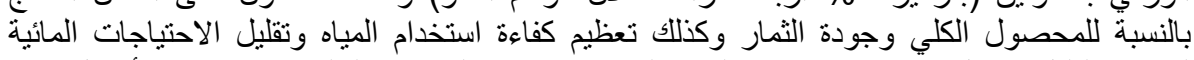

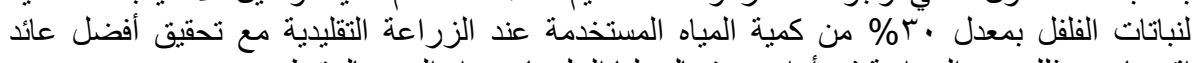
اقتصادي وذلك عند الزراعة في أراضي شمال دلتا النيل باستخدام الري بالتتقيط.

كلية الزراعة -جامعة المنصورة

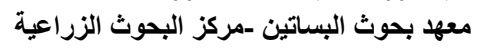

قام بتحكيم البحث

أ.د / كوثر كامل أحمد ضو البحه

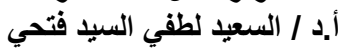

